\begin{tabular}{|c|c|c|}
\hline Name & $\begin{array}{c}\text { Average copper } \\
\text { present } \\
\text { Per cent }\end{array}$ & $\begin{array}{l}\text { Copper found } \\
\text { Per cent }\end{array}$ \\
\hline Vanadium steel No $24 \ldots \ldots \ldots \ldots$ & . $\quad 0.022$ & 0.020 \\
\hline Chrome nickel steel No. $32 \ldots$. & 0.056 & 0.056 \\
\hline Chrome vanadium steel No. $30 \ldots$ & 0.070 & 0.066 \\
\hline Nickel steel No. $33 \ldots \ldots \ldots \ldots \ldots \ldots$ & 0.150 & 0.150 \\
\hline No. 5 A iron (C)... & 0.060 & 0.063 \\
\hline
\end{tabular}

As a further proof of the accuracy of this method, known amounts of pure electrolytic copper containing 99.88 per cent of copper were added to the Bureau of Standards' sample No. I4 A steel. The mixed drillings were dissolved in $20 \mathrm{cc}$. of (2-I) nitric acid, $8 \mathrm{cc}$. of sulfuric acid (sp. gr. I.84) added and the solution evaporated until sulfuric acid fumes were evolved freely. The solution was allowed to cool and then $25 \mathrm{cc}$. of cold water were added and the solution was heated until all the sulfate was dissolved. The solution was filtered and the filter washed with hot water. The volume (not to exceed $75 \mathrm{cc}$.) was brought to a boil and the sheet aluminum introduced. Procedure was the same as stated before, except that after the solution was decanted through the filter and washed with water, the copper was dissolved on the filter and the filtrate rece ved in an electrolytic beaker and electrolyzed as usual. The results obtained follow:

Copper added
Per cent
0.499
0.998
1.997
2.996
3.995
4.994

Copper found
Per cent
0.49
0.99
1.97
3.00
3.99
4.98

I wish to give credit to Mr. George Shuster of the laboratory force, who tried out this method and obtained the results stated above.

William B. PRICE

WATERBURY, CONN.

Oct. 25,1913

INTERNATIONAL ELECTRICAL CONGRESS, I9I5.

The International Electrical Congress is to be held at San Francisco, September 13-I8, I9I5, under the auspices of the American Institute of Electrical Engineers, by authority of the International Electrotechnical Commission and during the Panama-Pacific International Exposition. Dr. C. P. Steinmetz has accepted the Honorary Presidency of the Congress. The deliberations of the Congress will be divided among twelve sections which will deal exclusively with electricity and electrical practice. There will probably be about 250 papers. The first membership invitations will be issued in February or March, I9I4.

Attention is drawn to the distinction between this Electrical Congress and the International Engineering Congress which will be held at San Francisco during the week immediately following the electrical congress. The engineering congress is supported by the Societies of Civil, Mechanical and Marine Engineers and by the Institutes of Mining and Electrical Engineers, as well as by prominent Pacific Coast engineers who are actively engaged in organizing it. This Congress will deal with engineering in a general sense, electrical engineering subjects being limited to one of the eleven sections which will include about twelve papers, treating more particularly applications of electricity in engineering work.

The meeting of the International Electrotechnical Commission will be held during the week preceding that of the Electrical Congress.

\section{SPRING MEETING OF THE AMERICAN CHEMICAL SOCIETY}

The Forty-ninth General Meeting of the American Chemical Society will be held in Cincinnati, Ohio, April 8-11, 1914.
The officers of the local section are: President, F. W. Weissmann, 2900 Vine St., Cincinnati, Ohio, and Secretary, Stephan J. Hauser, I623 Maple Avenue, College Hill, Cincinnati, Ohio. A more complete statement of the meeting will appear in the March issue of This Journal. The titles of papers should be sent to the Secretary, Charles L. Parsons, Box 505, Washington, D. C.

The following chairmen of committees have been appointed: Executive Committee, Frederick W. Weissmann.

Finance Committee, Archibald Campbell.

Transportation and Excursions, Gordon Farnham.

Press, Publicity and Printing, C. T. P. Fennel.

Reception and Registration, J. W. E1lms.

Ladies' Reception, Mrs. J. W. Ellms.

Entertainment, Richard Lord.

Smoker, F. C. Broeman.

Banquet, L. W. Jones.

Meeting Places, John Uri Lloyd.

Chas. L. Parsons

\section{BUREAU OF STANDARDS' ANALYZED SAMPLES}

The Bureau of Standards, Washington, D. C., is prepared to issue a sheet brass of the following composition, approximately:

\begin{tabular}{|c|c|c|}
\hline & Per cent & Per cen \\
\hline & 1.0 & Zinc.... \\
\hline Lead. . & 1.0 & Iron $\ldots \ldots \ldots \ldots$ \\
\hline Copper & 70.3 & Nickel..... \\
\hline
\end{tabular}

The fee, payable in advance is $\$ 3.00$ per sample of about I 50 grams weight.

January 6,1914

S. W. Stratton, Director

\section{SYNTHETIC RESINS-CORRECTION}

We note the following errors in our article under the above title, This Jorknal, 6, 3 .

(1) Page 8, Column I, four lines from the end, the equation should read:

" $2 \mathrm{HO} \cdot \mathrm{CH}_{2} \cdot \mathrm{C}_{6} \mathrm{H}_{4} \mathrm{OH} \longrightarrow \mathrm{HO} \cdot \mathrm{CH}_{2} \cdot \mathrm{C}_{6} \mathrm{H}_{4} \mathrm{O} \cdot \mathrm{CH}_{2} \cdot \mathrm{C}_{6} \mathrm{H}_{4} \mathrm{OH}$."

(2) Page ro, Column I, below the first table: " $\mathrm{C}_{6} \mathrm{H}_{3} \mathrm{OCH}_{2} \cdot \mathrm{C}_{6} \mathrm{H}_{4} . \mathrm{OCH}_{2} \cdot \mathrm{C}_{6} \mathrm{H}_{4}() \mathrm{OCH}_{2} . \mathrm{C}_{6} \mathrm{H}_{4} \mathrm{OH}$."

(3) Page ${ }_{13}$, Column 2, line nine from the end: "79 per cent" should read 76 per cent.
L. V. REDMAN
A. J. WEITH
F. P. BROCK

January 21,1914

\section{VEGETABLE OILS EXPORTED FROM CHINA, I9I2}

The Oil, Paint and Drug Reporter states that exports of vegetable oils from China in 1912 amounted to 35,046 net tons of bean oil, 20,28I net tons of peanut oil, and 44,815 tons of wood, tea seed and other oils.

\section{ANNUAL TABLES OF CONSTANTS, ETC., VOL. III.}

Volume III of the Annual Tables of Constants and Numerical Data, Chemical, Physical and Technological, published by the International Commission of the VIIth and VIIIth International Congresses of Applied Chemistry is now in press and will be issued in the first half of I9I4. A descriptive circular with references to reviews of previous volumes may be secured on application to The University of Chicago Press.

The subscription to Volume III is now opened and will be closed March 3I, 19I4. The names of subscribers should be sent to The University of Chicago Press, the American agent for the distribution of the Annual Tables. Subscriptions are payable to The University of Chicago Press at the time of publication.

The subscription price of Volume III will be the same as for Volume II, namely, $\$ 6$ for the unbound copy, $\$ 6.80$ for the 
bound copy (carriage free). Members of contributing societies (The American Chemical Society. The American Electrochemical Society, The Society of Chemical Industry, the American Academy of Arts and Science, the National Academy of Science) and of contributing manufacturing establishments, are entitled to a discount of 20 per cent (but not on the binding) and will receive the volume unbound for $\$ 4.80$, or bound for $\$ 5.60$ (carriage free) provided their subscriptions are received by March 3I, I9I4.
After March 3I, 19I4, the price will be raised to $\$ 6.40$ (unbound) and $\$ 7.20$ (bound) and a charge will be made for carriage and no discounts allowed.

JuLIUS STIEGLITz, University of Chicago

EDWARD C. FRANKLIN, Leland Stanford University

HENRY G. GALE, University of Chicago

AlBERT P. MATHEWS, University of Chicago

\section{PERSONAL NOTES}

Prof. Theodore William Richards, of Harvard University, has been elected President of the American Chemical Society for the year I9I4. M. T. Bogert and A. D. Little have been elected directors, and C. H. Herty, Julius Stieglitz, L. H. Baekeland and W. L. Dudley, councilors-at-large, for a three-year period.

An Anglo-American Exposition to celebrate the centenary of peace and progress in the arts, sciences and industries of the United States and Great Britain, will be held in London, from May to October. A committee has been organized to represent the chemical industries.

Dr. C. E. K. Mees, Director Research Department, Eastman Kodak Company, gave a lecture illustrated with lantern slides, on the problems, equipment and organization for research, in their plant at Kodak Park, Rochester, before the New York Section of the A. C. S., on January gth, at The Chemists' Club.

Mr. A. K. Comins, formerly in the leather department of A. D. Little, Inc., of Boston, is now with the A. C. Lawrence Leather Company, of Peabody, Mass.

The Wisconsin Section of the A. C. S. met on January 2 Ist. Prof. David Klein gave an illustrated lecture on "Recent Developments in Colloid Chemistry."

Mr. H. E. Howe, of the Bausch \& Lomb Company, gave an illustrated lecture on "Optical Glass" and "The Projections of Spectra," before the Western New York Section of the A. C. S. on January 13 th.

Sir William Crookes has been elected President of the Royal Society. In view of the invariable practice that the President of the Royal Society should hold no office in similar learned societies at the same time, he has been obliged to resign the Presidency of The Society of Chemical Industry, to which he was elected at the annual meeting in 1913.

Dr. Rudolph Messel was elected President of The Society of Chemical Industry, by the Council, on December 22nd, to complete the unexpired term of Sir William Crookes.

The Philadelphia Section of the A. C. S. held their January meeting on the 22nd. The speakers were Dr. Carl L. Alsberg, Chief of the Bureau of Chemistry; Mr. Charles J. Hexamer, of the Fire Underwriters' Association, who gave an illustrated address on "The Chemistry of Fires, and Chemicals in Fires." Prof. Philip Maas, of the Central High School, exhibited a suite of liquefied gases.

Prof. R. A. Wetzel, of the College of the City of New York, spoke at a recent Colloquium of the General Electric Company Research Laboratory, on the "Relativity Principle," which he illustrated with the models recently described in Science.

Mr. Wm. Hoskins and Mr. H'V. Main gave a lecture illustrated with lantern slides, before the Chicago Section of the A. C. S. on January I6th, on "Atmospheric Pollution."

Dr. Reston Stevenson has been promoted to the position of Assistant Professor of Chemistry in the College of the City of New York.

Dr. Wolfgang Ostwald, of the University of Leipzig, Germany, is giving a series of six lectures on colloid-chemistry before variou; universities and chemical organizations in America, includ- ing: Columbia, Chicago, Johns Hopkins, Illinois, Cincinnati, Nebraska, McGill (Montreal) Universities, Indianapolis Section of the A. C. S., and others to be arranged later.

The Alabama Section of the A. C. S. was addressed at the January 24 th meeting by Prof. B. B. Ross, on "The Occurrence and Composition of Some Alabama Phosphates," and by Prof. C. L. Hare, on "A Study of the Chemical Composition of Cotton Seed."

The International Petroleum Commission of Karlstuhe, Grand Duchy of Baden, Germany, desire to change the Commission into an International Petroleum Institute, and have requested the Imperial German Government to submit their plan to the countries represented or interested in the Commission.

Mr. Christian Dantsizen and Mr. J. A. Orange, of the General Electric Company Research Laboratory at Schenectady, have recently returned from Europe where they spent three months visiting plants of general interest to the electrotechnical industry.

The Johns Hopkins Medical School has announced the following changes concerning the admission of students: In I9I3 the number of students in each class was limited to ninety. In order to receive consideration applications of incoming stuclents must this year be made by July ist. After that date the various applications will be sifted and the most likely ninety applicants chosen. The requirements for admission in chemistry have been increased so that in addition to the present requirement of $5_{50}$ hours of laboratory work in inorganic chemistry, an additional 90-I00 hours of laboratory work in organic chemistry will be required of all students desiring to enter the school after October, I 9 I4.

Virgil Coblentz, Chief Chemist for Squibb \& Co., took the lucky number in a raffle, entitling him to the library and chemical publications of the late William McMurtrie. The drawing was conducted by Dr. Charles Baskerville and was held at The Chemists' Club, New York City, on January 9, I9I4.

The Southern California Section of the A. C. S. had as speakers at their meeting on January I6th, Dr. Elbert F. Chandler, of Occidental College, "The Universal Equilibrium," and Mr. H. J. Lucas, of Throop College of Technology, "The Sanitation Service of Porto Rico."

Prof. J. Howard Mathews, of the Chemistry Department of the University of Wisconsin, lectured on "Color Photography," before the Chicago and Indiana Sections of the A. C. S., on December 12 th and 13 th, respectively, and before the students of De Pauw University on the afternoon of December rath.

Mr. H. J. Skinner, Vice-President of Arthur D. Little, Inc., Mr. Perry Barker and Mr. Vasco Nunez, of the same organization, spent two weeks in December examining a large industrial plant in Louisiana.

The Cornell, Rochester, Eastern and Western New York and Syracuse Sections of the A. C. S. held a joint meeting at Syracuse University on January 17 th. The afternoon program was as follows: "Address of Welcome," Hon. Louis Will, Mayor of Syracuse; "The Use of Physical Measurements in 